\title{
The Humanization of Prison Spaces
}

\section{Cordeiro SF*}

Faculty of Architecture and urban planning, Brazil

ISSN: 2639-0574

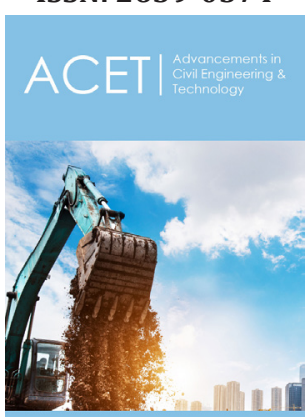

${ }^{* 1}$ Corresponding author: Cordeiro SF, Faculty of Architecture and urban planning, Brazil

Submission: 侮 May 14, 2019

Published: 䟧 May 28, 2019

Volume 3 - Issue 3

How to cite this article: Cordeiro S. The Humanization of Prison Spaces. Adv Civil Eng Tech. 3(3). ACET.000561.2019. DOI: 10.31031/ACET.2019.03.000561

Copyright@ Cordeiro SF, This article is distributed under the terms of the Creative Commons Attribution 4.0 International License, which permits unrestricted use and redistribution provided that the original author and source are credited.

\begin{abstract}
This short communication discusses how the scarcity of studies on criminal architecture in Latin America results in a reduction in the number of architectural and engineering solutions and opposes the vast scientific production in the field of human sciences, which seeks to understand prison reality and transformation / improvement of the punitive system. Here, the autor proposes the need to develop research and humanization strategies for prisons in order to contribute to the process of architecture design and construction of the penal building, while there is no other form of social control than deprivation of liberty.
\end{abstract}

Keywords: Prison architecture; Humanization of spaces; Prison space and human rights; Prison architecture as social technology

\section{Introduction}

Contemporary architecture is in a period of technological transition and cultural values, although it considers each historical time which belongs a line of thinking and a production resulting from these thinking that reference space-time. The materialization of these ideas had different methods of construction, linked to cultural values of the time, resulting in buildings considered as an expression of the concepts and theories of each historical moment. Thus, from the characteristics of an architecture it is possible to speculate about the characteristics of the society that produced it.

The walled institutions have a particular characteristic in that part of the individual's duties is to participate visibly, at appropriate times, of institutional activities, the requirement of a mobilization of the community, a certain surrender of self to the activities (considered) suitable for functioning of the institution. In the specific case of the Prison architecture, the realization of concepts is sometimes unknown by the society, a fact that complicates understanding of the penitentiary system, bringing to emerge the necessity to present them, in order to describe it as an analytical element the planning of prison spaces.

\section{Discussion}

Since the XVIII century, society defends the discourse of "humanization of punishment spaces" and this definition is addressed in contrast to what is considered as inhuman spaces(impressive buildings with monumental facades, only bricks, without any trace of trees/green in the surroundings and not well maintained, building inside of multiple long corridors, dominated by the sound of artificial lighting and the noise of air conditioning, devoid of windows, grilled, with insufficient natural lighting). The manipulation and customization of the environment by the user is nearly impossible. There is a general lack of maintenance and care, combined with over-order and sterility. The attention for the humanization of spaces is present in the architectural discourse about hospitals, schools and prisons.

When we explore the theoretical basis for humanization of the contemporary hospital architecture, which is closely connected to the evolution of health care [1-4] and to its institutions, this is defined as a dynamic process of recovery, restoration, renovation and transformation that increases the potential of the healing of patients. When also refer to the humanization in school architecture, we have discussed the pedagogical trends and their architectural responses, and emphasize which steps are most important in the design process in order to realize humanization, namely the drafting of the architectural program and the 
development scope of the project, always supported by research that focuses on design strategies.

For prison the humanization was introduced in pursuit of the social rehabilitation of the offender. To be in line with International Treaties (UN Standard Minimum Rules, Bangkok Treaty, etc.), countries have improved their Criminal and Penitentiary Policies by incorporating requirements regarding the treatment of prisoners, their rights (e.g. education, receive visit) and needs, which in turn are related to the way prison spaces have to be used. However, it must be clear that (for the construction of prisons) no reference to spaces and the use of it has explicitly been made until now. Although several countries in Latin America do recognize the need to improve prison architecture [5-7] in line with the humanization discourse, they keep making the same mistakes because they fail to deepen knowledge related to prison spaces.

Because it is a space of security, considering the need for careful control and strict discipline, like the managers of the prison system told, it is considered here, the necessity to understand the strategies and spatial solutions necessary to the improvement of functionality and security of units, as well as aspects of humanization. We can even observe new problems with building conditions, such as absence of adequate ventilation and natural lighting; undersized hydro-sanitary installations; the repetition of Panoptic or Telegraph Pole type (resulting in long corridors with cells on both sides, far from the control of the prison officer) $[8,9]$.

In order to talk about prison architecture we first need to take into consideration the different types of prisons and, of course, of prisoners. The prisoners are classified using criteria such as: sex, age, race, physical and psychological state and sentence, and the prisons are ranked by: a) the type of prisoners and, also, b) by an administrative criteria. Concerning the type of prisoners, for example, there are male and female prisons that vary by security levels, however, respect for human rights and diversity brings together several subcategories of gender that deserve to be considered: maximum security prison, closed prisons and semi-closed prisons. Considering the administrative criteria, the following types of prisons can be distinguished: state prisons, private prisons and hybrid prisons. State prisons are built and run by the state, the guards are public officials.. Private prisons are built and managed by an independent administrator and are popular in the US. The state pays a fee for the inmates in the prisons care. Hybrid prisons are the ones run in a partnership between the state and a private investor. There are two type of hybrid prisons: built by a private company and run by the state and prisons build by the state and managed by an independent administrator [10].

However, this classification does not take into consideration the role of a prison and the place of a prison in society, even though this would be necessary to capture the difficulties in designing and building prisons that allow for humanization as well as security. Conflicts in combining security and humanization aspects within prison architecture arise from the often opposing requirements of these two concepts. Security, for example, requires view control and, as a consequence, large and high spaces that therefore are most of the time noisy as well. Humanization, on the contrary, requires a human scale (i.e., space in proportion to user's body) that takes into account the perception and experiences of the different users (e.g. prisoners, staff, visitors of different kind). Furthermore, prison architecture is complex given the fact that a prison is a dynamic entity with varying numbers of prisoners as well as different relations between people, between space and people, and between distinct flows, especially due to the amount of activities and environments necessary for the operation of this institution.

Prison architecture can differ depending on the choice of: a) the formal type, which can be recognized by basic shapes and/or formal characteristics [11] and b) the functional type, which indicates the functions of the building. The formal types are monastic, panoptic, telegraph pole, campus, modules, mix, cross, etc. In Table 1: Formal typologies in prison architecture) [12-14]. For example, semi-open prison buildings frequently are configured according to campus models with remote modules and open circulation space (this shape allows greater freedom of movement inside the prison, with landscape view possibility, open spaces,...), whilst the private prisons are based on the telegraph pole or panoptic typology, to reduce handling of prisoners and number of employees and thus increase control (the concentration of flows and the central control favour the discipline and control of movements).

The functional typology can differ depending on the profiles of the offenders (e.g. classification along the potential violence, sexual orientation, gender, ...), the kind of sentence (e.g. short vs long stay or convicted versus detention on remand), the administrative body that is responsible for the prison (e.g. state, private and privatepublic prisons). For example, the geometry of the cells modules developed in the United States, which relate to location of control room (in the centre of the module, with or without barriers, with the cells in a triangular position or in the centre aisle, with isolated control).

As demands for new prison constructions, because of overcrowding in Latin America, designers seek materials that present characteristics such as Speed in building construction, Structural Stability, Fire resistance, Resistance to use, Sealing, Hygiene, Durability, Reduced costs, Quality, impermeability, resistant to external physical and chemical attacks, with integrated color, however, little attention is paid to aspects such as personal space, ventilation and natural lighting sufficient for health and disease prevention, urban infrastructure necessary for the implementation of the prison building, as well as all kinds of services for prisoners' relatives and employees of prison. When looking at the architecture from a social, cultural and administrative point of view, the purpose of a prison is to rehabilitate the people that committed an illegal act and to separate them from the community until they pay their dues. But also we can identify a symbolic role, a symbol for power and reparation in a totalitarian society. Despite this, the Humanization concept is arranged in two categories: a sense of urbanity and sense of habitability, focusing respectively on the territorial arrangement and at the building scale [15] and the need for indicators related 
to aspects of sustainability [16], permeate the project development methods, among others, defining how many primary axes projective parameters and various subcategories of analysis.

The sense of urbanity refers to the scale deployment of buildings, seeking to provide the urban liveliness, the perception of a sense of place and harmony with the environment, thus contributing to the spatial connectivity, legibility and identity. On the other hand, the sense of habitability includes the scale of the concepts of the building itself, and aims to provide, from basic needs, a sense of inhabiting that "meets the needs of shelter, insulation, coexistence, order and variety that category includes three subcategories concepts: spatial harmony, environmental comfort and privacy; sense of home; choice and flexibility. Thus, to understand the functional typology, we also have to take into account aspects as: a) human conditions and safety of prisoners, b) work conditions of staff, c) ambience created in prison, d) human rights considerations and e) life experience of living and working in prison. The information provided above elucidates the deficits in knowledge concerning the different types of prison architecture in relation to prison goals, humanization possibilities, and influences on individuals operating within prisons. More precisely, according to recent research $[17,18]$, depending on the prison goal (Rehabilitation etc.), the different "humanized aspects" are incorporated in the prison architectures to varying degrees $[17,18]$.

We highlight five distinct levels of variables: 1) the classification of prisoners and their allocation; 2) functional issues such as sectorization, flowchart, organization chart, interactions between environment, etc; 3) architectural level issues such as constructability $\mathrm{x}$ guarantee of safety, capacity for future enlargements, flexibility of use considering space versus time; 4) implementation of criminal units in urban or ruralareas; 5) operating conditions, rationality, etc. However, it remains yet unclear how the different goals are related, how potential relationships between the types as well as the according standards of architectural language can be identified, and how prison units should be designed in order to ensure safety and humanization. Although taking into account the concern with the organization and physical structure of the institutions, vocational training, work relations and production logic, with instruments related to structural changes and opening a range of possibilities to increase the quality of spaces and also to a new relational order seeking humanizing, it is considered that the theoretical and practical foundation in the field of humanization of space, needs more in exploration and investment [19-22].

\section{Conclusion}

The scarcity of studies on prison architecture results in reduced number of architectural solutions and is opposed to the vast scientific production in the field of human sciences, which seeks to understand the prison reality and the transformation / improvement of the punitive system as a mechanism to prevent violence through joint interdisciplinary conceptual aimed at humanization of system. A socio-technical adequacy has significant importance to design projects development processes and, subsequent, architectural spaces. To transcend the static and normative view, the sociotechnical adequacy can create/develop possibilities of innovative solutions and greater strength and effectiveness of criminal policy and current penitentiary.

\section{Acknowledgement}

Professor Geert Vervaeke; National Counsel of Technological and Scientific Development (CNPCP).

\section{References}

1. Lawson B, Bassanino M, Phiri M, Worthington J (2003) Intentions, practices and aspirations: Understanding learning in design. Design Studies 24(4): 327-339.

2. Lawson B (2005) How designers think: the design process demystified. ( $4^{\text {th }}$ edn), Oxford: Elsevier $\backslash$ Architectural, UK.

3. Lawson B (2007) Language of space. Routledge, UK.

4. Verderber S, Fine DJ, Fine DJ (2000) Healthcare architecture in an era of radical transformation. Yale university Press, USA.

5. Fairweather L, Mcconville S (2000) Prison architecture: Policy, design and experience. Oxford: Architectural Press, USA.

6. Johnston NB (2000) Forms of constraint: A history of prison architecture. University of Illinois Press, Chicago, USA.

7. Lima SFC (2009) De perto e de dentro: As relações entre o indivíduo preso e o espaço arquitetônico penitenciário a partir de lentes de aproximação, Edufal, Maceió, Brazil.

8. Lima SFC (2015) Reflexões sobre a autoria do lugar. Vitruvius, São Paulo, Brazil.

9. Sun WY (2014) Construções penais. thesis (doctorate)-Programa de Pós-Graduação, Faculdade de Arquitetura e Urbanismo, Universidade de Brasília, Brazil.

10. Moldan A (2012) Prison architecture: Classification by objectives, Advanced Research in Scientific Areas, UK.

11. Voordt TJM, Wegen HBR (2013) Architecture in use. An introduction to the programming, design and evaluation of buildings. Oxford: Elsevier, UK.

12. McConville S (2000) The architectural realization of penal ideas. In: Fairweather Leslie, Sean McConville (Eds.), Prison Architecture: Policy, Design and Experience, Great Britain, Architectural Press, UK, pp. 1-16.

13. Lima SFC (2013) Entre Celas e Cancelas: descrevendo o espaço do sistema penitenciário a partir da teoria ecológica do desenvolvimento. $6^{\circ}$. Projetar, Salvador, Brazil.

14. Wener RE (2012) The Environmental psychology of prisons and jails: Creating humane spaces in secure settings. Cambridge University Press, USA.

15. Kowaltowsky D (1980) Humanization in Archtecture: analysis of themes through high school building problems. (Thesis, PHD). Graduate Division. University of California, Berkerley, USA.

16. Kowaltowsk YD, Celane MGC, Petreche JBD (2007) An evalution method for school building design at the preliminary phase with optimization of aspects of environmental confort for the school system of the stat of São Paulo in Brazil. Building an Environment. Pergamon Press, UK 42(2): 984-999.

17. Lima SFC (2016) Prison architecture and humanization. Discussion about interdisciplinary research, involving architecture, psychology and criminology Inspirational Lunch Restorative Justice in Institute of Criminology LINC, KU Leuven, Belgium. 
18. Lima SFC, Vervaeke G (2016) Study of humanization in projectual pattern language of european prisons. Research of Pos doctorate Report, KU Leuven, Belgium in: National Counsel of Technological and Scientific Development-CNPQ. Science without Borders Program-CsF, Brazil.

19. Gesler W, Bell M, Curtis S, Hubbard P, Francis S (2004) Therapy by design: evaluting the UK hospital building program. Health \& Place, UK 7: 117-128.

20. Lima SFC (2015) A construção do sujeito no/pelo espaço penitenciário, Conference in Faculty of Architecture and urban Planning, Coimbra, Portugal.
21. Lima SFC (2016) $7^{\text {th }}$ Global Conference Experiencing Prison; Inst. promotora/financiadora: interdisciplinar network Place Near and Inside: descibing the prison environment, Budapest, Hungary.

22. Useem B, Piehl A (2006) Prison buildup and disorder. Punishment \& society, London, Thousand Oaks, CA and New Delhi 8(1): 87-115.

For possible submissions Click below: 